\title{
INKPADUTA'S CAMP AT SMITHLAND
}

\author{
By Miriam Hawthorn Baker
}

The author of the following manuscript is the great-granddaughter of David T. Hawthorn, one of the early Smithland settlers (see article), and the granddaughter of William $F$. Hawthorn. Mrs. Baker, a farm homemaker, writes a weekly column entitled "From the Kitchen Window" for the Sioux City Journal's farm supplement; and, for seven years, she taught an "Iowa" unit in junior high social studies. She is the wife of Carl E. Baker, Moville, Iowa.

Mrs. Baker spent a tremendous amount of time researching the Smithland incident and obtaining the following photographs and we hope her meritorious effort will influence Iowans to mark this historical site near Smithland.

A frightening experience for a Woodbury County pioneer mother, Mrs. David T. Hawthorn, and her four small children preceded the Spirit Lake Massacre. The menacing visit of Inkpaduta and nine of his war-painted braves to the Hawthorne cabin near Smithland has heretofore been chronicled only in long-ago issues of local newspapers and pioneer sketches, ${ }^{1}$ and has never before been included in an Iowa publication having wider circulation. (The Hawthorns' story and statements by Joseph Henry Taylor in Twenty Years on the Trap Line ${ }^{2}$ were evidently not known to Thomas Teakle when he wrote The History of the Spirit Lake Massacre ${ }^{3}$ nor to the compilers of The History of the Counties of Woodbury and Plymouth. ${ }^{4}$ )

Because the Hawthorns' story has significance in showing the dramatic change in the behavior of the band of Wahpekute (Siouan) Indians who committed Iowa's most henious massacre, their experience deserves to be added to the comparatively meagre recorded information concerning events at Smithland in the winter of 1856-57.

What factors prevented the Hawthorns from being robbed and abused as were the unfortunate settlers a little farther up

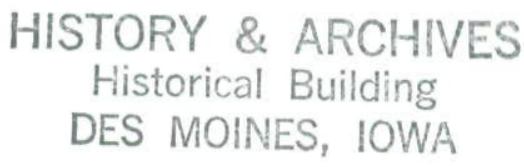


the Little Sioux River? What saved them from being murdered as were the pioneer families on Okoboji and Spirit Lakes? How did this family, visited just after the Indian band had been antagonized by Smithland "vigilantes," escape the tragic fate of the Gardners, the Howes, and all the other victims of Iowa history's bloodiest chapter?

To answer, we can only examine the few existing records and bits of evidence which form the background of the story. Since historians have never dealt exhaustively with the happenings at Smithland, it is important to establish: (1) the Indians' presence near Smithland and the Hawthorn cabin in the months preceding the massacre, (2) the Adams and Hawthorn families' situations as Smithland Pioneers, (3) the nature of the Indians' conduct in the Smithland locality, (4) Elijah Adams' relationship of trust with Inkpaduta's band, and (5) the deteriorating Indian-white relationship in the Smithland community during the winter of 1856-57.

The call on the Hawthorns, as one of the last events, if not the very last, before Inkpaduta and his band started up the Little Sioux and committed their notorious series of depradations and killings will then appear as a vital link in the chain of events. It may also serve to explain the postponement of the Indians' revenge.

Inkpaduta's Presence Near Smithland and the Hawthorn Cabin

According to J. Wallace Adams, who wrote his recollections and who was also interviewed by journalists upon a number of occasions, Inkpaduta and his small band of Wahpekute Indians arrived in the Smithland area about Dec. 10, 1856, and camped beside the Little Sioux River. The camp was located on the farm land owned by Elijah Adams, father of Wallace Adams. Wallace and his brother Harry were watering their horses at the river when they first saw the Indians. "Ten or twelve ponies dragged the tepee poles, loaded with tents and a few papooses. They pulled up the bank right in front of us, proceeded to clean off the snow and erect their nine tepees. They used water out of that same waterhole all winter." Wallace Adams was 15 years of age at the time of the Indians' arrival; Harry Adams was 13.

Mary Hawthorn Bouslaugh, relating her pioneer experiences in The Castana Times, stated that "with the exception of 
the family of Elijah Adams ... our only neighbors were hostile Indians."

Hattie Elston, ${ }^{6}$ who interviewed Wallace Adams, wrote that the Indians came to the Adams farm in mid-December, 1856, and remained there until about March 1. "History books," she comments, "had given all kinds of stories about that winter and had located the band in Minnesota, Dakota, and near Lost Island Lake in Iowa. . . . The camp was on the Adams farm, two miles upstream from the little village of Smithland, which had been laid out by O. B. Smith. The Indians lived there all through that cold, terrible, starving winter. . . There were 35 persons in the party on the Adams farm, fifteen of them carried guns so that must have meant there were fifteen warriors. There were nine tepees, Mr. Adams remembered very well, indicating five married couples. A half-breed, Charlie, and Gunn, his brother, were in the party. . . . Inkpaduta had his wife and four sons with him at the Adams farm. Three were married, one was single. The twins Kam-pe-a-ho-to-man (Roaring Cloud) and Mak-pi-op-e-ta (Fire Cloud) were 'fat fellows' and the younger son, then a tall handsome lad of about 17, was surly and sullen and generally ill-tempered...."

The History of the Counties of Woodbury and Plymouth ${ }^{4}$ states: "In the late fall of 1856, a band of renegade Indians, headed by Inkpaduta, came into Little Sioux Twp. and camped. There were 22 of them, all, or nearly all of them being outcasts from the Sioux and Winnebago tribes."

Although The Iowa Journal of History and Politics ${ }^{7}$ gives a later arrival date-“It was this (Inkpaduta's) band which suddenly made its appearance in Feb. 1857 at the small village of Smithland in southeastern Woodbury County ... departed within a few days"-Abbie Gardner herself did not. She says, "In the autumn of 1856, Inkpaduta's band went down to the lower valley of the Little Sioux, where the first trouble with the whites began in the vicinity of Smithland."

A. R. Fulton ${ }^{9}$ wrote that in the spring of 1855 Indians had generally withdrawn from the upper Des Moines and the lakes in Dickinson County, giving white settlers the impression that all danger had passed. In 1856, however, straggling bands began to make their appearance and "even ventured as far 
(east) as the vicinity of Ft. Dodge. They feigned the appearance of friendship for the whites. . ." Fulton stated (speculated?) that Inkpaduta's band was encamped in Dickinson and Emmet counties during the winter in question. But he went on to say that in February, 1857, "Inkpaduta and about 50 of his men (should this have been 15 rather than 50 ?) were in the lower part of the valley of the Little Sioux hunting elk...."

Taylor ${ }^{2}$ gives the date of November, 1857, as the time of Inkpaduta's arrival at Smithland, but proceeds to tell of the disarming of the camp and the subsequent trip to the massacre which occurred, he says, in March, 1857. He or his printer evidently erred on the former date.

Dr. Giles C. Moorehead ${ }^{10}$ said "Inkpaduta and his band lived on the Little Sioux about Smithland. All these tribes ... from time to time visited the Maple Valley for hunting and trapping."

A History of Dickinson County, Iowa, recorded that "Inkpadutah [sic] and his band left their camp at Loon Lake some time in December and went south down the Little Sioux as far as Smithland. ... There is no record that Inkpadutah's [sic] band had any trouble with the settlers on their way down the river. Whether they went by way of the settlements or not, is not known. There is no account of their being seen by the settlers here at all on their way down the river, and it is more than probable that they went from the head of Spirit Lake down the divide to Lost Island Lake. Up to this time they were supposed to be friendly, that is, as friendly as usual. They were never cordial; always sullen and suspicious. The settlers at Smithland knew but little, if anything, of the previous troubles of this band of Indians with the settlers of the older localities, and they had no apprehensions of serious difficulty. ${ }^{11}$

If the testimony of the eye-witnesses and the consensus of historians is to be accepted, there is no question of the Indians' presence on the Adams land near the Adams and Hawthorn cabins in the months just preceding the Spirit Lake Massacre, March 7-13, 1857. 


\section{Arrival and Settling of the Adams and Hawthorn Families} at Smithland

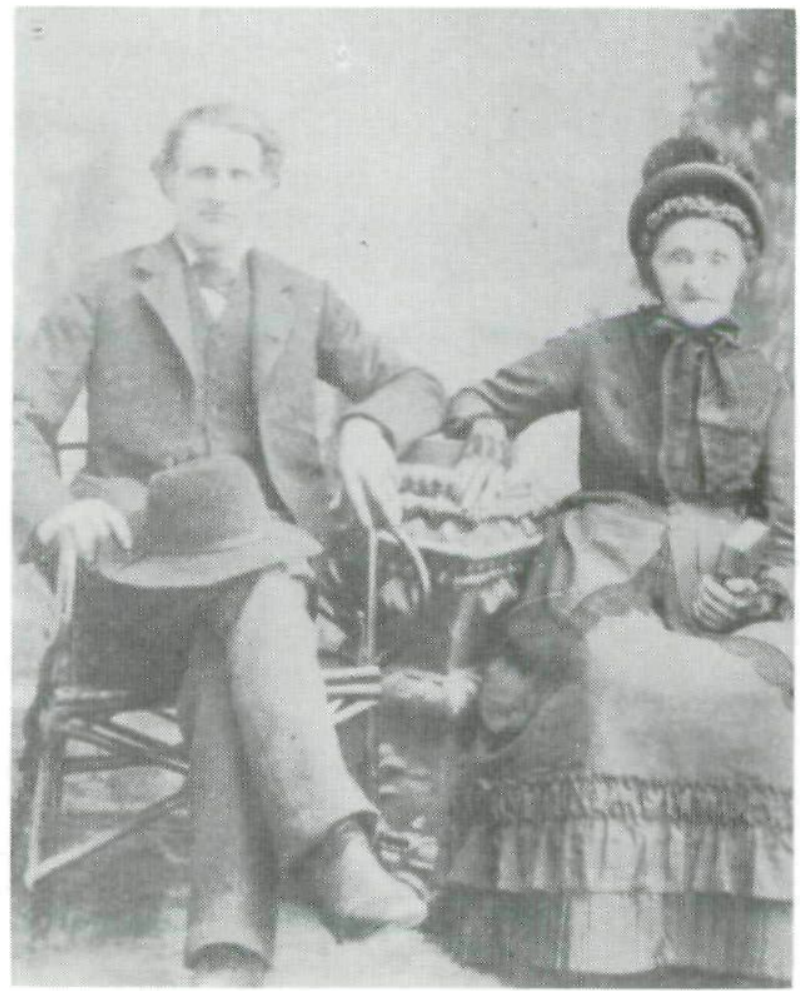

courtesy of Adams' descendant Bernadine Sarff

Mr. \& Mrs. Elijah Adams of Smithland

A caravan of 23 persons, including the families of Elijah Adams and David Thomas Hawthorn, arrived at Smithland on June 5, 1856. Adams, the leader of the caravan, had prospered in Illinois, and brought 100 head of cattle to Iowa. He had purchased 320 acres of land in Little Sioux Township @\$3.60 an acre in the fall of 1855 . In the caravan he was accompanied by his wife, Rebecca Buntin Adams, and 4 children, Elizabeth, Wallace, Harry, and G. E. "Lige." The Adams couple had both been born in 1814 in Kentucky, he, near Boonesboro and she, near Carlisle. In 18.30 their respective families moved to 
Boone County, Ind., where Rebecca and Elijah married in 1837. In the autumn of 1844 they moved to Rock Island County, Ill., taking their three children who had been born in Indiana, and residing there until the spring of 1856. "Lige" was born while the family lived in Illinois and was three years of age when he came to Smithland.

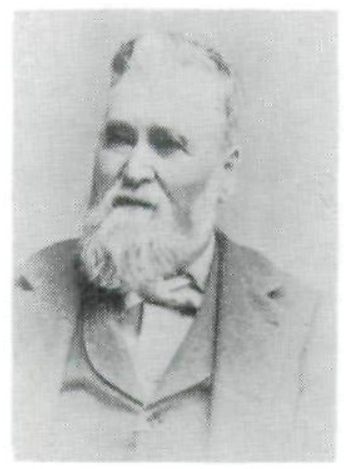

conirtesy of F. W. Hawtborn

\section{David T. Hawthorn}

The Hawthorns were natives of Maryland, both having been born in Washington County. David T. "first saw the light of day Sept. 29, 1828." ${ }^{\prime 2}$ $\mathrm{He}$ attended the school at Hagerstown, Md. His bride was Catherine Harshberger. They married Dec. 21, 1848 , and the following spring moved to Rock Island County, Ill., where they became acquainted with the Adams family. Hawthorn had worked for Adams in Illinois and had agreed to assist Adams with his livestock when they set out for the Iowa frontier. The Hawthorns were accompanied by three of their children when they came to Woodbury County, Mary, John, and Virginia (Jenny or Gin), having left their frail eldest daughter, Kate, with her grandparents in Maryland, where she died at the age of seven.

Ox teams pulling five covered wagons and two open wagons brought the caravan to Iowa. Besides the Adamses and the Hawthorns there were Mr. and Mrs. Henry Martin, George and Everett; Priscilla Austin, Lucinda and Lavina; Rebecca Butler Smith, John Kimmer, Landon Hughes, Tom Naples, and Elijah Craig. Smithland (the oldest town in Woodbury County-founded 1853) had a population of about 25 people who were living in half a dozen $\log$ huts at that time.

According to James A. McDonald, whose family had settled at Smithland in $1854^{1}$ (also having come from Illinois), most of the migrating families slept in their wagons until their shanties were built. What is now Smithland's park was used as a camping spot by the pioneers. McDonald's family lived in this manner more than a month. Their cabin had only one 
room, about 20 feet square, with a fireplace in one end. His father made a table out of the center of a maple log, driving stakes in the earthen floor to support it. Later there was a puncheon floor. Chairs were made from split logs.

By contrast Wallace Adams recalled that his parental home was a house $16 \times 32$ feet, and 12 feet high "with a partition across the middle and good room upstairs. The chimney was made of mud and sticks in one end. A cabin such as this was better than most of the pioneers could take time to build." The family moved in about Oct. 15, 1856, not having had time to dig a well. Mary Hawthorn Bouslaugh wrote that her father built a log cabin in the fall out on the open prairie, just east across the river from what is now the town of Smithland. "There was no habitation in sight, and with the exception of the family of Elijah Adams, who came with us, our only neighbors were hostile Indians."

Readers may wonder why these pioneer families did not raise their cabin shelters sooner. Breaking the prairie, planting, and harvesting were the tasks of first importance. Only a week's rest was allowed the oxen after the arduous journey. By the last of July the Adamses (father and two older sons), D. T. Hawthorn, and the hired men had turned over 100 acres of sod, using two yoke of four oxen each and two 24-inch breaking plows. It was time to go into the hay fields to provide feed for the 100 head of cattle they had driven over the plains from Illinois. By early fall 150 tons of meadow hay had been cut and stacked.

The haying had not been finished long when calamity struck. A prairie fire, roaring up from the south (where a settler wanted to frighten some blackbirds), destroyed twothirds of the precious hay-the hay that meant life for the cattle during the bitter winter that was just around the corner.

All during the winter of 1856-57 the Adams and Hawthorn families depended upon a water hole in the Little Sioux River, for themselves and for their livestock. The women had gathered wild plums and wild grapes, preserving as much as they could. The men had butchered three wild hogs, left behind by the Mormons, and kept the meat frozen in the attic for their winter supply. They had milk and butter, and had laid in a stock of staples before the December 1 blizzard. 
(Some of the men probably made a trip to Kanesville, now Council Bluffs, the usual source of their supplies.)

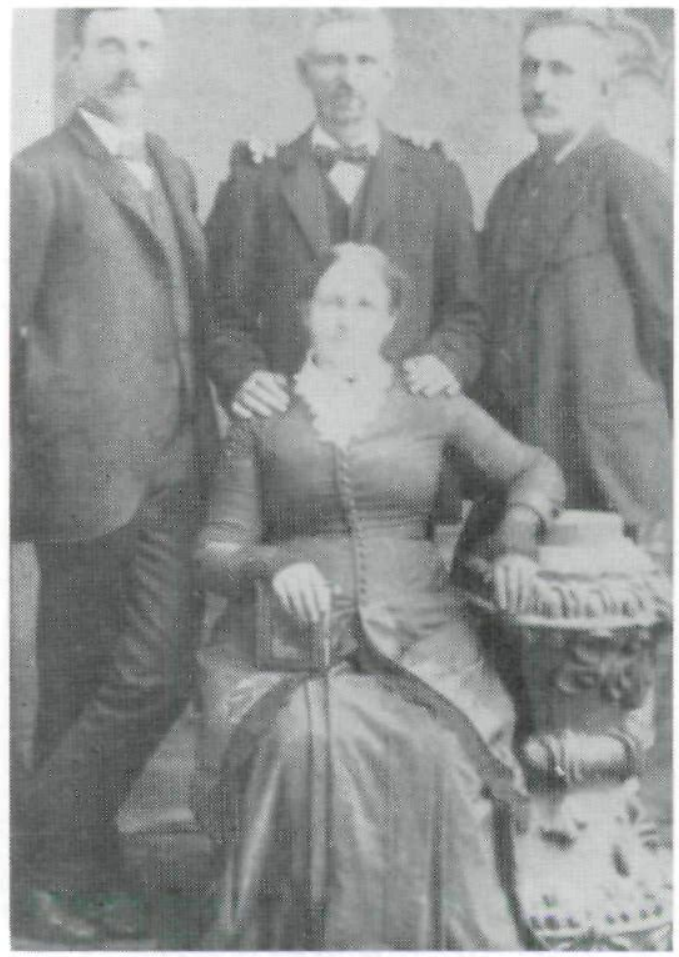

courtesy of Mrs. Bernadine Sarff

The four children of Elijah Adams. "Lige" was 3, Wallace 15, Harry, 13, and Elizabeth, 16. when the family settled at Smithland in 1856 .

\section{Inkpaduta's Band Appeared Friendly}

The first "Smithlander," Curtis Lamb, who settled in Woodbury County in 1851, had a good word to say for lnkpaduta. ${ }^{13}$ He even entrusted his wife and children to the Indian's care when it was necessary to make a trip to Kanesville for supplies. If logs were needed for the fireplace, Inkpaduta sent squaws to carry them in. He kept Mrs. Lamb's table supplied with fresh fish and venison in her husband's absence. Lamb learned the Sioux language from Inkpaduta, according 
to his own account. In one of their first encounters, when Inkpaduta and his warriors were in an ugly mood, Lamb succeeded in pacifying them with some of his best turnips. The Indians at first spurned his offering, but later tasted the turnips and accepted with thanks.

According to Lamb's descendant, Vernon Blank, "for three successive autumns, the now friendly Indians camped on Lamb's place and traded with him. Every spring the Indians went north to where the wild ducks and geese laid their eggs. Lamb became the Indians' trader, lending them steel traps to help with their hunting, which they returned in the spring. They would trade elk, deer, otter, mink, beaver, wolf, fox and other skins and venison hams, which he hauled to Kanesville, ninety miles south, to sell for cash."

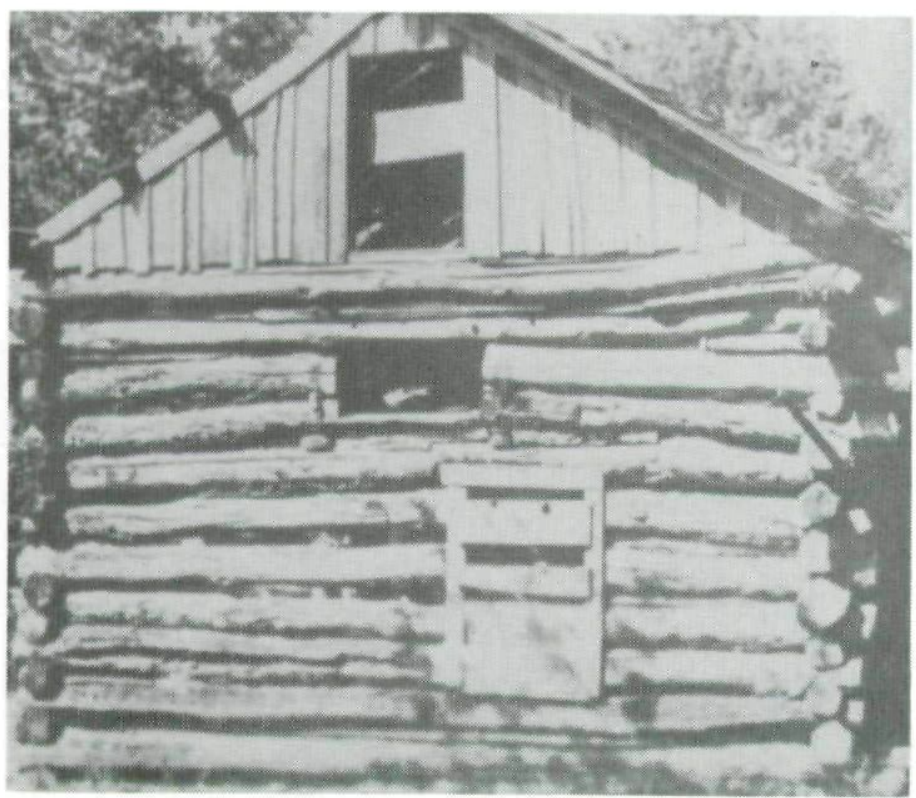

Photo by G. E. Wendel

The cabin of Smithland's first settler, Curtis Lamb.

When the Lamb family moved to Sioux City in the spring of 1856 , they rented their farm to a Mr. Livermore. The Indians, coming down in the late fall of 1856 , as was their custom, 
found new settlers, some of whom did not want them there. The band camped on Adams' land rather than on the farm rented from Lamb by Livermore.

After the arrival of Inkpaduta and his band near Smithland, and their encampment on the Adams farm two miles upstream in mid-December, 1856, "almost daily the boys (Wallace and Harry Adams) met their red-skinned neighbors at the water hole." The squaws frequently visited Mrs. Adams and her daughter at their log house, seeking to exchange bead work and other handerafts for clothing and food. When weather permitted, the men went hunting. "The Indians were quiet and sociable all winter," and his family had no reason to fear them, according to Wallace Adams, "much less to imagine that within a short time they would become fiends and murder an entire settlement."

In the words of James McDonald, "The Indians were friendly, always begging for something." Mary Hawthorn Bouslaugh recalled that "every day some of the Sioux Indians visited our cabin on a begging expedition. My mother, afraid of them, would divide what little food she had with them." The squaws were especially eager to trade venison for pork. As food became more and more scarce, the Indians lived on the cattle that were dying daily near their camp.

Teakle $^{3}$ indicates that "the approach of the Indians was not noticed at white settlements because so many traders and trappers had been driven in by the severe winter. . . no no alarm was felt at Smithland ... where the Indians appeared friendly . . . begged ... were supplied by the settlers. ..."

William J. Petersen was no doubt correct in declaring that "during the hard winter of 1856-57 Inkpaduta and his followers probably suffered just as much as his more peacable brethren."

\section{Elijah Adams' Relationship with the Indians}

Wallace Adams related that "The very next day after they came and erected their 9 tepees, 7 or 8 of the braves came to our house ... with their big pipe of peace and we all took a whiff. ... They seemed to be a sociable bunch, all except old Inkpaduta, who was gruff and sullen, 60 years old and pockmarked. Some of them were in our house nearly every day and we were in their camp, so I got well acquainted." In his "Grandfather's Story" column he also mentioned that "our 
folks knew all of those Indians personally, as some of them were in our home nearly every day warming and smoking. . . . $\mathrm{He}$ (Inkpaduta) was never in our house. . . . The squaws visited us and we traded pork and corn for venison, moccasins, and other things."

In her recollections Mary Hawthorn (Mrs. Marion) Bouslaugh referred to Elijah Adams as the "agent" of the Indians. Her nephew, journalist Willard Robbins ${ }^{1}$ explains that Adams was not officially appointed, but acted as an agent might have: "He had a great deal of influence with the Indians, and often traded with them." The leader of the caravan of 23 persons who came to Iowa from Rock Island County, Illinois, was known as a "good provider." Before the howling storm of Dec. 1, 1856, bore down upon the Iowa prairie he had built the new log house and chinked it well. When other families were having a "tough time" of it that winter, the Adams family were able to draw upon their large store of provisions and to share with the Indian neighbors. As Wallace Adams remembered, the Indians made use of some of the cattle that died in the terrible winter, but they did not help themselves to any of their friend Adams' surviving cattle despite their hunger.

\section{Deteriorating Indian-White Relationship}

A letter written by John Lamb (son of Curtis Lamb, the first white settler in the Smithland vicinity) indicated that the pioneer family of his parents was threatened by Inkpaduta and "four of his best warriors" in the Lambs' first autumn in Woodbury County. The Indians "came to our house with the intention of killing us (in 1851). My father gained their friendship by treating them kindly and giving them food. At that time there were lots of elk, deer, buffalo, wild turkey by the thousands, and cougar. The river was alive with fish and there was wild fruit of every kind. We were all neighbors and truly enjoyed ourselves. When the Indians came down in the fall, my father would trade with them for fur and hides. He never traded them any alcoholic drink but sometimes he would give some of them a drink of milk, and oh, my! did they like that!"14

Although the wily Inkpaduta was known as one who "supported himself by hunting and plunder, leading a wandering, 
marauding life," he and his followers had evidently been tolerated by Smtihlanders for several years before the hard winter of 1856-57. He had been refused the annuity payment in 1854, as well as in 1856, at the Redwood Indian Agency. That humbling experience was not exactly new to him in 1856 .

Severe weather over an extended period seems to have been the factor of difference in 1856-57. During the weeks and months of December, January, and February, human endurance and human patience were strained to the breaking point. Both G. E. Adams and Mary Hawthorn Bouslaugh have referred to their respective mothers' emotions in that period. Catharine Hawthorne was distressed at having to keep on dividing meager supplies with the Indians, but felt that she dared not refuse them. Rebecca Adams suffered "a long and anxious period" before the Indians left. The pioneer women's annoyance and fear could scarcely have gone unnoticed by the begging Indians.

The Indians had not been camped on the Adams farm long that winter before they discovered unhusked corn under the deep snow in a field below (south of) the Smithland settlement. They set the squaws to gathering it. As the Indian women passed through the settlement, carrying corn in blankets slung on their backs, they were accused of stealing it from cribs. The History of the Counties of Woodbury and Plymouth states that O. B. Smith and John Howe procured switches and began whipping the squaws, who dropped their burdens and ran to the camp, pursued and punished all the way. "This so aroused the ire of the Indians that they began to kill the settlers' cattle in revenge."

When a large drove of elk appeared in the timber on the river bottom, the nearly famished Indians began preparation for a hunt. After the hunt was well under way an Indian was attacked by a settler's dog which had joined in the chase. "The Indian retaliated by killing the dog. Then the owner of the dog sought to even matters by administering a rather severe beating to the Indian, at the same time forcibly disarming him." 3 and 8

David H. Boot of Iowa City, writing to the Open Forum Editor of the Des Moines Register, ${ }^{5}$ blamed whisky for another "incident." He said the account was given him 40 years earlier 
(than 1933) by "the old Methodist preacher who had been the early circuit rider of that region and who got his information at Smithland. "The circuit rider reportedly arrived at Smithland not long after the affair. His story had O. B. Smith and "a number of other young scoundrels" filled up on whisky and out to have "a drunken man's good time." Some of the Indian women were supposedly along the river hunting for clams. The drunken whites allegedly chased the squaws, who fled to their camp for protection, losing some of their possessions in the river. "The Indian camp," wrote Boot, "broke up in terror and fled up stream, while their pursuers returned well pleased with what they had done."

Wallace Adams took quick issue with this tale by writing to the Open Forum to correct Boot's statements. Adams' letter said in part, "I have a list of those 21 young men, taken from a history of Plymouth and Woodbury counties, published in 1890. I knew every one of them both before and after this event. The last one died about 8 years ago, but they left a numerous progeny who don't like to hear their fathers classed as 'drunken scoundrels.' Five or six of the men, and maybe more, would take a little drink, but I never knew of any of them being drunk. ... As to Mr. Boot's story of . . Indian women gathering clams, how could they gather clams under ice 2 feet thick and snow 4 feet deep?"5

Teakle made a comment on the deteriorating Indian-white relationship at Smithland: "The settlers now assumed a plainly unfriendly attitude toward the Indians, which in turn gave impetus to a change in the temper and attitude of the Indians toward the whites. They soon became sullen and insolent, with a manifest tendency to commit a variety of malicious acts, probably for the purpose of trying the temper of the settlers. Only acts of a trivial character, however, were actually committed; and so the wiser heads in Smithland were successful in warding off for some time any serious trouble."

The story of the "militia" or "vigilantes" who finally took matters into their own hands is well authenticated. Though half a dozen sources vary as to some details, the disarming of Inkpaduta's band by about 21 Smithlanders evidently took place late in the winter of 1856-57. Wallace Adams said late February, but Jane Bicknell's diary ${ }^{13}$ recorded that Inkpaduta's 
band was already in the Peterson vicinity by mid-February. Perhaps this is just a problem of what people mean by the terms "late" or "mid." The figure 21 for the number of "militia" is given in several accounts, but careful research has never uncovered more than 18 settlers' names: Seth Smith, Eli Lee, John Howe, Eli Floyd, Jim Kirby, M. L. Jones, O. B. Smith, Wm. Turman, Ed Howe, John Kinnea, Thos. Nagle, M. B. Mead, Thos. Davis, Wesley Turman, John Floyd, Thos. Bower, Jonathan Leach, and A. Livermore. Who the others were may never be established. But the Adams recollections show that none of that family participated, and Taylor states ${ }^{2}$ that D. T. Hawthorn "had refused to be a party to the disarming of Inkpaduta's hunting camp, characterizing it as an unjustifiable proceeding, lacking cause."

Seth Smith was chosen leader of the militia. He lived just across the line in Monona County, but was identified with Little Sioux Township "in everything except actual residence. $\mathrm{He}$ came from Ohio and had been a major in the militia. He had brought a full suit of regimentals-cocked hat, gilt epaulettes, glittering sword, and split tail coat, and these evidences of greatness made him a man of mark. He was chosen captain of the group 'partly because he was a good man for a leader and partly because he owned that magnificent suit of regimentals'."'

The Smithland "militia" found that some of Inkpaduta's band were away hunting. (History of Woodbury and Plymouth Counties says "most of the band," but Taylor says 4 bucks were hunting.) The posse surrounded the camp, then demanded that the Indians leave the vicinity. Inkpaduta protested. ${ }^{2}$ He pointed out that the snow up north was so bad that they could not get anything to eat there, but said that his band "would like to go down to the Omaha reservation and shake hands and bury the hatchet. The white men did not care where they went, but wanted them to go and go at once, and said they would help their red brothers to get started for the Omahas in the morning. Capt. Smith and his men, however, thought a little precaution might be a good thing, so they took the guns from the Indians, promising to bring them back in the morning." ${ }^{14}$ Hattie Elston's book says 
the Indians were told to stop by the town for their guns enroute south. "Inkpaduta called attention to his people's hapless fate in being deprived of their guns, which were almost the only means of obtaining food for their dependent families." ${ }^{\prime 2}$ But his remonstrance was in vain.

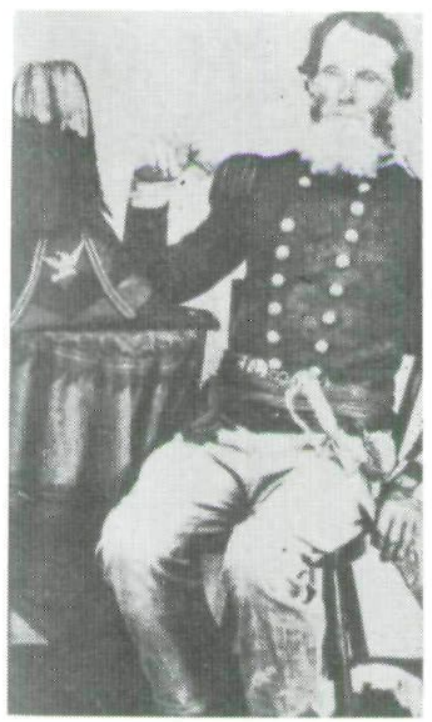

courtesy of Dr. E. E. Gingles

Seth Smith, early settler near Smithland, former major in the Ohio militia, chosen to lead the Smithland posse who disarmed Inkpaduta and his band.

In The Iowan Blank reported that when the white men appeared at the Indian camp, the squaws and children took to the woods." The white men tore down the tepees, took the guns and ammunition and went home, intending, it was claimed, to go back later and return the guns and tell them what they wanted. It was obvious according to Lamb that they did not understand Indian nature for when they went back the next morning, the Indians were gone, having moved in the night. Insulted and injured as they felt, Lamb insisted it was no wonder that the Indians concluded to 'borrow' some white men's guns in the same way theirs had been borrowed." ${ }^{13}$ 
There can be no question as to the Indians' anger. Taylor, ${ }^{2}$ who obtained information in the 1860's from his trapping friend, David Hawthorn, says that if the "white trappers of the Smithland party had understood 'signing up' the dying embers of an Indian's camp fire as familiarly as they did a beaver slide, they might have at least made some attempt to stay the storm caused by their overofficiousness. The 'sign' left by the departing Indians (was composed of) a few small upright sticks placed near the embers where the chief's lodge stood. It would read to a party of four absent hunters, on their return, to avoid all parties of white men, take care of their guns, and join them (the band) as soon as possible further up the valley of the Little Sioux. The Indians joined forces near the Correctionville settlement. . . ." As Abbie Gardner sadly recalled $^{8}$ "They went up the Little Sioux, their hearts filled with revenge, and committed depredations as they went."

Fulton and Teakle both relate another story, that since the Sioux all feared General Harney, holding him in a sort of superstitious awe or dread, a Smithland settler donned the soiled uniform of an army officer and at sunset appeared in the edge of the timber on the bank of the Little Sioux opposite the Indian camp. Somehow it was suggested to the Indians that this was Harney, in close pursuit of them, and they fled the same night. "As they fled it became increasingly evident that they were thirsting for revenge. From suffering indignities themselves, they now turned to the infliction of atrocities upon whosoever chanced to cross their path. While the more levelheaded settlers at Smithland regretted the tricks played upon the Indians, all congratulated themselves upon being rid of their unwelcome guests." 'But in the words of Wallace Adams, "The people made a fearful mistake when they drove them away, for this was the direct cause of the Spirit Lake Massacre."

"Yet another version of the "General Harney" story is recorded in A History of Dickinson County, pp. 53-54. It appears to be a combination of two or three of the incidents included in this piece, and evidently is less accurate. 


\section{The Call on the Hawthorns}

Only two events have been recorded as taking place near Smithland in the brief time between the "militia's" disarming Inkpaduta's band and the Indians' leaving. Had these occurrences been known to all the Smithlanders, and had they been at once communicated to other pioneer settlements, the bloody massacre at Spirit Lake and the series of crimes along the Little Sioux might have been prevented.

Both events happened on the Adams farm. Judging from written accounts, not even all the members of the Hawthorn and Adams families were aware of both the swapping of buffalo robes for a gun and the terrorizing of Catharine Hawthorn and her small children. Wallace Adams recalled that the Indians came to his father's home on the evening of the day when the posse had disarmed the camp. He spoke of the wanting to trade either four buffalo robes or their best pony for a light double-barreled shotgun. Not having learned about the posse's action, the Adamses were willing to trade. Probably this was the only gun the band had when they started north, until the four braves who had been out hunting joined the rest at Correctionville with their firearms.

David Hawthorn, referred to in Taylor's book as "Trapper Hawthorne," was frequently absent from home for long periods. He trapped beaver "all over" northwestern Iowa, going as far as Storm Lake and Spirit Lake, and even into Minnesota. Whether he engaged in much trapping during the severe winter of 1856-57 is not recorded. But his herding cattle that winter for Elijah Adams, a Mr. Bayliss, Thomas Flowers, John Truman, and Frederick D. Winegar, on the banks of the Missouri River in Franklin Township, Monona County, is chronicled in the History of Monona County. ${ }^{12}$ As a result of the loss of the hay in the prairie fire (see section on "Arriving and Settling") Hawthorn and a man named Edward Young were engaged as herders, and took the cattle to the rush beds to keep them from starving.

Hawthorn's wife and four children were alone in their cabin when Inkpaduta's band gave them the fright of their lives. In addition to Mary, John, and Virginia, who had accompanied their parents from Illinois in the covered wagon, there was now an infant brother, William Franklin, born Feb. 


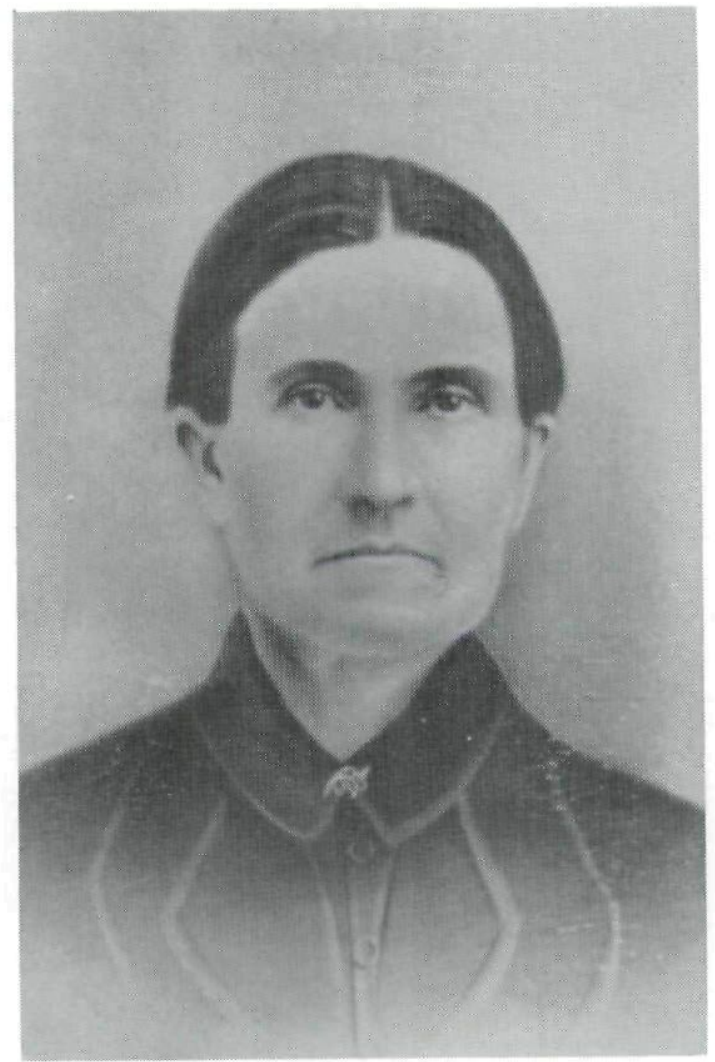

courtesy of F. W. Hawtborn

Catharine (Mrs. David T.) Hawthorn, pioneer mother who was terrorized by the Indians near Smithland in February, 1857.

3, 1857. Mary, the eldest of the four, was then seven years of age. In her words: "One never-to-be-forgotten morning the door opened slightly, as the Indian always enters, and in came two Indians with war paint and head dress on. We had never seen them so before, and anyone who has never seen an Indian painted up for the warpath has no idea how diabolical they can make themselves appear, with the red and black paint. In a little while two more came in, and so on, until with their chief, Inkpaduta, there were ten warriors sitting around our stove and very nearly filling up our little cabin. 
"Then to our horror, they began to take from their robes their scalping knives, tomahawks, and whetstones and began to sharpen them before our eyes. Once in a while they would pass their fingers over the blades of their knives and look back in the corner where my mother and we three small children were crouched awaiting our doom." One Indian pointed at the baby in the cradle nearby, and then drew his knife blade across his throat in a suggestive manner. He could see Catharine Hawthorn's fright, and apparently was having his little joke.

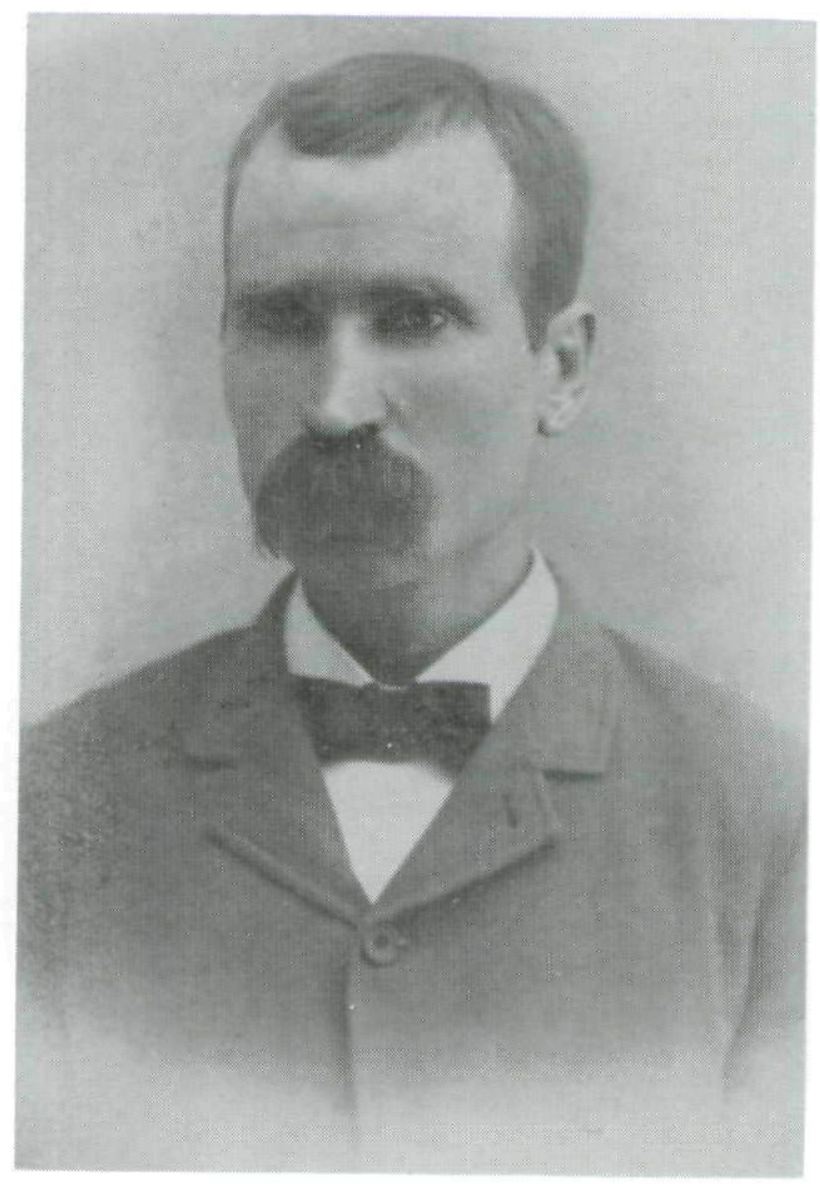

courtesy of H. B. Hawthorn

David Hawthorn, infant threatened by Indians. 
In Mary's words, "It seemed to us it took them hours to sharpen their tools, and during the time they used our supply of fire wood pretty freely." The braves had placed corn on the stove to parch, as was their custom, and it was not parching as fast as it should because the fire was low. Mrs. Hawthorn saw her chance. As Mary remembered, "It was then my mother thought of a plan. The Indians knew that the Adams boys cut our wood for us during the absence of my father, and knowing that several of the Indians could understand English, my mother said, loud enough for them to hear, 'Mary, you will have to go and tell the boys to cut us some more wood.' But when she stooped to fasten my cloak she whispered, 'Go and tell Mr. Adams to come quickly, the Indians are going to kill us! "

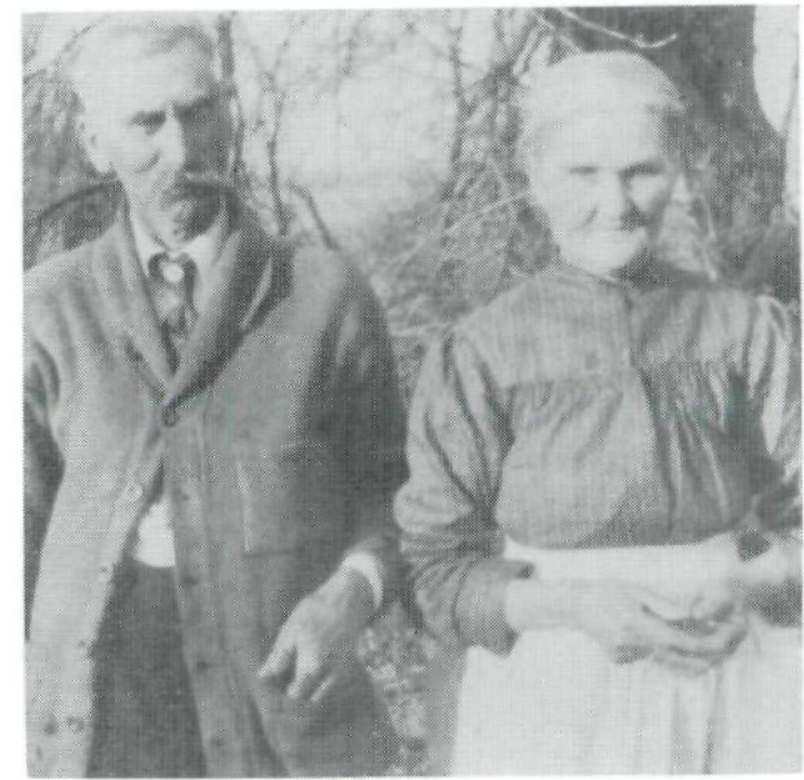

courtesy of Maynard Smith

Mary Hawthorn Bouslaugh and her husband, Marion Bouslaugh. Photo taken in the early 1920s.

Alburtus Hawthorn reported the family recollection ${ }^{1}$ that Mary was afraid to walk by the Indians near the door, so she climbed out the window. "The Adams home was over a hill 
from our place," she recalled, "and I will never forget how glad I was when I saw Mr. Adams at the barn, where I could call to him. He had a pitchfork in his hand, which he threw down and started on a run for our house, and picking up a snowshoe that stood outside the door, he went in and routed out the whole band. (Alburtus says he used the expression "puck-a-chee" meaning "get out!") There was no other man living who could have accomplished such a feat. Mr. Adams was their agent. (Robbins' book explains that he was not officially appointed but acted as an agent might have.) $\mathrm{He}$ gave them their ammunition and blankets, and nothing could have induced them to harm a hair of his head. But I often think of the bravery of this man who could rush in on ten armed warriors with no other weapon than a snowshoe.

"The Indians went on down to the river, where they had their tepees, and that night we could hear them whooping as they danced their war dance preparatory to starting next morning for Spirit Lake, where they committed the awful massacre...."

A very similar account of the call on the Hawthorns appeared in Mapleton Milestones, probably based on Mary Hawthorn Bouslaugh's recollection in the Castana Times, adapted by her younger sister, Belle Hawthorn (Mrs. William) Rawlings.

If the Smithland incidents were the direct cause of the series of crimes committed all the way from Correctionville to Spirit Lake, why did the depradations not begin in the Smithland community? Inkpaduta never took any chances with soldiers, and he probably considered the vigilantes to be soldiers. But he surely had no fear of an unprotected woman and her little children. He and his braves were deeply aroused, and painted for war. Evidently the only barrier to their commencing at once to wreck vengeance upon the whites was the character and determination of Elijah Adams. Had Adams been less fair with Inkpaduta's band in his past dealings, or less commanding in his sudden appearance at the Hawthorn cabin, who knows what might have taken place?

Long afterward, in 1865, six of Inkpaduta's band stalked Hawthorn and Joseph Jackson as they trapped Mill Creek. ${ }^{2}$ But though the Indians followed for 20 miles, they did not 
harm the two trappers. Perhaps, even then, there was respect for Hawthorn as a friend of Elijah Adams, and as one who did not participate in the disarming of the camp at Smithland.

(Author's note: Rev. Alonzo Pruitt, who wrote the historical column "I May Be Wrong" for The Smithland News during the 1930's, concluded one of his weekly stints by saying, "I am wondering, with such interesting history, why the site where this band of Indians, headed by Inkpaduta, camped the winter of 1857 just north of Smithland on the Elijah Adams farm, has not been marked while there are yet living people who know the locality where the camp was located. A large boulder, similar to the one marking the site of the first school house in the county, would be all right set by the state highway, and could also be seen from the railroad."

To date the site is still unmarked. Pruitt may occasionally have "been wrong," as all historians occasionally are. But in this suggestion about the historical marker, those who prize their heritage would say he was unquestionably right!)

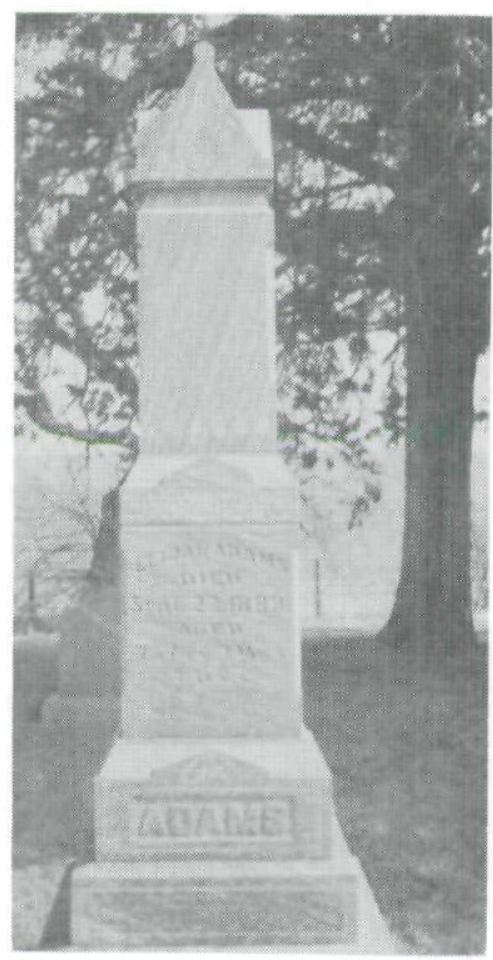

Photo by Dale Baker

The grave of Elijah Adams, located northeast of Smithland in a pioneer cemetery. 
The graves pictured below are located in Center Township Cemetery, Monona County, near Castana, lowa.

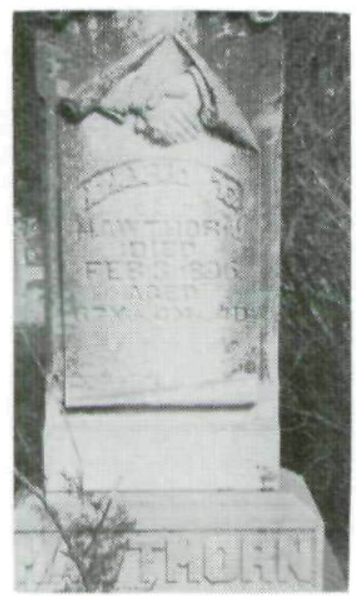

Grave of

David T. Hawthorn

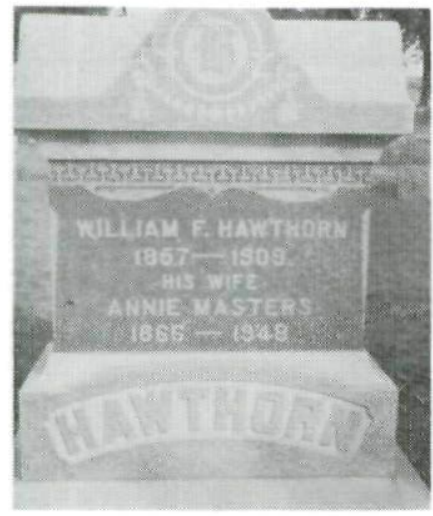

Grave of William Hawthorn photos by Dale Baker

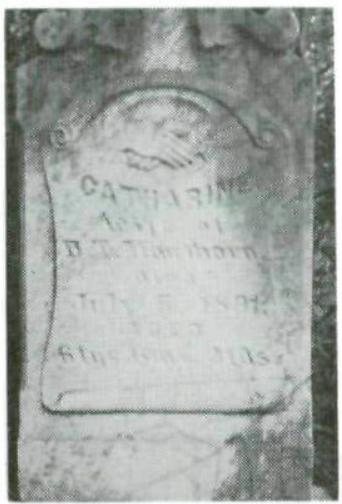

Grave of Catharine Hawthorn

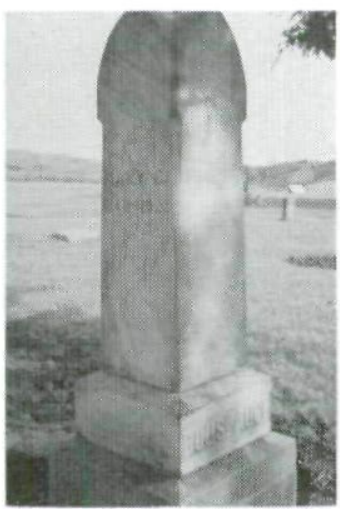

Grave of Mary Hawthorn Bouslaugh 


\section{FOOTNOTES}

${ }^{1}$ Clippings from The Castana Times and The Smithland News; Mapleton Milestones (compiled by Mapleton Women's Civic Improvement Club, Fort Dodge: Kepler Printing, 1938) pp. 24, 111-112; Recollections of Monona County Pioneers (Robbins, Willard, Mapleton: Mapleton Press, 1929).

${ }^{2}$ Taylor, Joseph Henry, Twenty Years on the Trap Line, Bismarck, North Dakota, and Avondale, Pennsylvania: Privately Published, 1891, pp. 13-18, 42-43, 48.

${ }^{3}$ Teakle, Thomas, The History of the Spirit Lake Massacre, Iowa City: State Historical Society of Iowa, 1918, Chapter X.

${ }^{4}$ History of the Counties of Woodbury and Plymouth, Chicago, Illinois: A. Warner \& Co., 1890-91, pp. 305.

${ }^{5}$ Des Moines Register, “Open Forum," Dec. 17, 1933 and Nov. 26, 1933.

${ }^{6}$ Elston, Hattie P., White Men Follow After, Iowa City: Athens Press, 1946, pp. 18-22.

${ }^{7}$ Iowa Journal of History and Politics (Benj. Shambaugh, Ed.), Iowa City: 1918, pp. 336-338.

${ }^{8}$ Palimpsest (Wm. J. Petersen, Ed), Iowa City: October, 1962.

${ }^{9}$ Fulton, A. R., The Red Men of Iowa, Des Moines: Mills \& Company, 1882 , pp. 300.

${ }_{10}$ Moorehead, Dr. Giles C., Historical Collections of Ida County, Ida Grove: Pioneer Record Press, 1928.

${ }^{11}$ Smith, R. A., A History of Dickinson County, Iowa, Des Moines: The Kenyon Printing \& Mfg. Co., 1902.

${ }^{12}$ History of Monona County, Iowa, Chicago: National Publishing Company, 1890, pp. 593, 415, 253-255.

${ }^{13}$ The Iowan Magazine (Dave Archie, Ed.), Shenandoah: Sentinel Publishing Co., February-March, 1956, Curt Harnack's "Prelude to Massacre" and December-January, 1960-61, Vernon Blank's “Inkpadutah's Great White Friend."

${ }^{14}$ Letter of John Lamb, printed in The Smithland News; Alonzo Pruitt's "I May Be Wrong" column in The Smithland News. 
Copyright of Annals of Iowa is the property of State of Iowa, by \& through the State Historical Society of Iowa and its content may not be copied or emailed to multiple sites or posted to a listserv without the copyright holder's express written permission. However, users may print, download, or email articles for individual use. 